\title{
INFILTRATING INFLAMMATORY CELL PHENOTYPES AND APOPTOSIS IN REJECTED HUMAN CORNEAL ALLOGRAFTS
}

\author{
D. F. P. LARKIN, R. A. ALEXANDER and I. A. CREE \\ London
}

\begin{abstract}
SUMMARY
Purpose: The aim of this study was to survey the histopathological and immunohistochemical features of rejected human corneal allografts.

Methods: Following graft failure in each case due to rejection, paraffin-embedded specimens of 17 corneal transplants which had been replaced were examined by light microscopy and immunohistochemistry. Specimens were either first $(n=9)$, second $(n=4)$ or third $(n=4)$ grafts and were removed at varying intervals from 4 weeks following documented rejection.

Results: Those grafts which were removed earliest following onset of rejection had the most intense graft inflammatory infiltrates. Immunohistochemical staining showed a high proportion of graft stroma-infiltrating cells expressing leucocyte common antigen, and many of these cells also bore $T$ cell or macrophage markers. Leucocyte-keratocyte apposition and regional loss of keratocytes were observed in all rejection specimens, but not in non-rejected control grafts. In situ endlabelling of DNA double-strand breaks and morphological features identified keratocyte apoptosis in 5 of 12 specimens examined for this phenomenon. Corneal endothelial cells were absent in 7 specimens and present in reduced numbers in the remaining 10 specimens.

Conclusions: Endothelial cell monolayer attenuation and keratocyte loss are consistent findings in grafts removed subsequent to clinically observed endothelial rejection. Death of donor corneal cells is mediated, at least in part, by apoptosis. The stromal inflammatory infiltrate consists mainly of $T$ lymphocytes and macrophages, which may be responsible for induction of keratocyte apoptosis.
\end{abstract}

All reports indicate that allograft rejection is the commonest cause of corneal transplant failure. The

From: Department of Pathology, Institute of Ophthalmology, Bath Street, London EC1V 9EL, UK.

Correspondence to: Mr Frank Larkin, MD, Moorfields Eye Hospital, City Road, London EC1V 2PD, UK. proportion of failed grafts attributed to irreversible rejection ranges from $42 \%$ to $27 \%$ in published series. ${ }^{1-3}$ However, there have been very few reports on the histopathology of graft rejection in patients, and because grafts are almost never removed at the time of rejection, those specimens studied represent treated or burnt-out rejection. Reported features of rejected human corneal grafts are loss of endothelium, a retrocorneal inflammatory membrane in some cases, vascularisation, superficial stromal scarring and a cellular infiltrate of mixed composition. ${ }^{4,5}$ The predominant cells are macrophages and $T$ lymphocytes, the majority of which carry helper $\mathrm{T}$ cell surface determinants. ${ }^{5}$ HLA class I and II antigens are expressed on corneal endothelial cells, stromal keratocytes and basal epithelial cells in rejected grafts. ${ }^{6,7}$ Intercellular adhesion molecule-1 (ICAM-1) is expressed on epithelial cells, keratocytes and endothelial cells, particularly at foci of mononuclear cell aggregation..$^{7,8}$ Vascular cell adhesion molecule-1 (VCAM-1) and the neutrophil ligand E-selectin have been found in some vascularised rejected grafts, expressed on vascular endothelial cells. 7,8 The extent to which some findings reported represent alloantigen recognition rather than rejection per se is uncertain.

Most of the available information on pathology of corneal graft rejection has been obtained from experimental transplantation studies, particularly in rabbit ${ }^{9-11}$ and rat ${ }^{12,13}$ models. In untreated rejecting rabbit allografts the cellular infiltrate within the graft is heterogeneous, containing macrophages, lymphocytes, plasma cells and neutrophils. ${ }^{10.14}$ An immunohistochemical study by Williams and colleagues ${ }^{11}$ has shown that half the leucocytes are $\mathrm{T}$ lymphocytes, two-thirds bore MHC class II markers and one-fifth carried myeloid cell markers. In rat cornea, which more closely resembles human cornea in terms of MHC molecule expression, ${ }^{15}$ tissue sections showed increased expression of MHC class I antigen and

Eye (1997) 11, 68-74 @ 1997 Royal College of Ophthalmologists 
donor MHC class II antigen in the graft. ${ }^{16,17}$ Neutrophils, macrophages, CD4+ and smaller numbers of $\mathrm{CD} 8+$ cells infiltrate the graft ${ }^{18}$ with most lymphocytes expressing the interleukin-2 (IL-2) receptor. ${ }^{17}$ Corneal graft rejection in the rat can be summarised as showing characteristics of a classical delayed-type hypersensitivity response, but no detailed information is available on mechanisms of corneal cell injury in rejection. The purpose of this study was to examine the histological and immunohistochemical features of rejected human corneal grafts and examine particularly for donor corneal cell apoptosis.

\section{Corneal Specimens}

\section{METHODS}

All specimens included in this study were from patients in whom immunological rejection was the sole apparent cause of graft failure. All had clinically observed rejection episodes at variable intervals prior to replacement of the graft. Any patient with a primary corneal disease, such as viral infection, which upon recurrence might render uncertain the clinical diagnosis of rejection, was excluded. For comparison, two graft specimens were examined which had not undergone any clinically evident rejection episode: one had been removed on account of untreatable graft astigmatism, and another following decompensation due to development of Fuchs' endothelial disease in the donor cornea. Corneal specimens removed at transplant surgery were fixed overnight in $10 \%$ formol saline, dehydrated in alcohols, embedded in paraffin wax and sections cut at $5 \mu \mathrm{m}$ thickness.

\section{Immunohistochemistry}

Unless otherwise specified, all primary antibodies were obtained commercially from Dako (High Wycombe, UK) and were directed against: human leucocyte common antigen (clones 2B11 and PD7/26), ${ }^{19}$ CD3 (T cells), ${ }^{20}$ CD20 (clone L26; B cells), ${ }^{21}$ CD57 (NK-1, Novocastra Laboratories, Newcastle, UK; natural killer cells), ${ }^{22}$ CD68 (KP1; macrophages, granulocytes), ${ }^{23} \alpha$-1-antichymotrypsin (monocytes, macrophages) ${ }^{24}$ and HLA-DR (LN-3, Novocastra). ${ }^{25}$ Biotinylated polyclonal swine antirabbit Ig, polyclonal rabbit anti-mouse Ig, and streptavidin-biotin-peroxidase complex were also obtained from Dako.

Dewaxed sections were processed as follows. Endogenous peroxidase activity was blocked with $3 \%$ hydrogen peroxide in distilled water, and sections were incubated at room temperature in sequence with normal serum: primary antibody for $60 \mathrm{~min}$, secondary antibody for $45 \mathrm{~min}$, and streptavidin-biotin-peroxidase complex for $45 \mathrm{~min}$. Sections were then washed in phosphate-buffered saline (PBS) and exposed to hydrogen peroxidediaminobenzidine (Sigma, St Louis, USA) substrate solution for $5 \mathrm{~min}$, washed in water and counterstained with Mayer's haematoxylin. For all antibodies, the positive control used was inflamed human tonsil; as a negative control, the primary antibody was omitted and the diluent only ( $2 \%$ albumin in PBS) substituted. To enumerate the proportions of graft inflammatory cells at the site of maximum infiltration, three adjacent microscope fields were examined at $\times 400$. Antibody labelling of graftinfiltrating cells was judged semi-quantitatively on a scale of 0 to +++ , where 0 indicated no visible inflammatory cells and +++ indicated a dense infiltrate.

\section{Examination for Apoptosis}

Cells with morphological characteristics of apoptosis on haematoxylin and eosin staining were identified by scanning one section of each specimen at $\times 400$ magnification, using standard histological criteria, ${ }^{26.27}$ and by an in situ and-labelling based method. ${ }^{28}$ Apoptotic bodies were identified histologically if they demonstrated three of the following four features:27 (i) ovoid or spherical shape, (ii) eosinophilia, (iii) separation from neighbouring cells, (iv) condensation and/or fragmentation of nuclear chromatin. As neutrophils are known to undergo apoptosis at inflamed sites in vivo, ${ }^{29}$ tissue sections with infiltrates of neutrophils were excluded from this analysis to avoid their confusion with apoptosis of keratocytes.

The in situ $3^{\prime}$-tailing reaction (ISTR) ${ }^{30}$ was used to detect DNA double-strand breaks of apoptotic cells. Briefly, sections were dewaxed and hydrated, endogenous peroxidase activity was blocked by the action of hydrogen peroxide in methanol and proteolytic pretreatment effected with $20 \mu \mathrm{g} / \mathrm{ml}$ proteinase $\mathrm{K}$ (Life Technologies, Gibco-BRL, Paisley, UK) in PBS at room temperature for 15 min. Sections were then exposed to a solution containing 0.3 units/ $\mu \mathrm{l}$ terminal deoxynucleotidyl transferase (TdT) (Gibco-BRL), $50 \mu \mathrm{M}$ dATP/ $25 \mu \mathrm{M}$ biotin-14-dATP (both Gibco-BRL), $100 \mathrm{mM}$ potassium cacodylate $(\mathrm{pH} 7.2), 2 \mathrm{mM} \mathrm{CoCl} 2$ and $0.2 \mathrm{mM}$ dithiothreitol (DTT) for $60 \mathrm{~min}$ at $37^{\circ} \mathrm{C}$. The ratio of unlabelled dATP to labelled dATP in the 3 tailing reaction was set at 2 . The incorporated biotin14-dATP was visualised by peroxidase-conjugated streptavidin (Dako) using diaminobenzidine (Sigma). Negative controls were sections incubated with 3'-tailing reaction solution without TdT; these were confirmed to be unstained.

\section{RESULTS}

A total of 19 replaced transplants were examined. Of these, 17 failed subsequent to allograft rejection, 1 
Table I. Patient details

\begin{tabular}{|c|c|c|c|c|c|c|c|}
\hline $\begin{array}{c}\text { Patient } \\
\text { no. }\end{array}$ & $\begin{array}{c}\text { Age } \\
\text { (years) }\end{array}$ & Original corneal disease & $\begin{array}{c}\text { No. of } \\
\text { previous } \\
\text { grafts }^{\mathrm{a}}\end{array}$ & $\begin{array}{l}\text { Cause of } \\
\text { graft failure }\end{array}$ & $\begin{array}{l}\text { Interval post- } \\
\text { transplant }\end{array}$ & $\begin{array}{l}\text { Interval post- } \\
\text { rejection }\end{array}$ & $\begin{array}{l}\text { Topical steroid at } \\
\text { graft removal }^{\mathrm{b}}\end{array}$ \\
\hline 1 & 25 & Stromal scar & 1 & Rejection & 9 months & 5 weeks & No \\
\hline 2 & 73 & Aphakic CO & 1 & Rejection & 2 years & 5 months & No \\
\hline 3 & 72 & Fuchs' endothelial disease & 1 & Rejection & 2 years & 4 weeks & No \\
\hline 4 & 35 & Stromal scar & 1 & Rejection & 2 months & 4 weeks & Yes \\
\hline 5 & 38 & Trauma & 2 & Rejection & 4 months & 9 weeks & Yes \\
\hline 6 & 51 & Dystrophy & 1 & Rejection & 21 years & 12 years & No \\
\hline 7 & 67 & Pseudophakic CO & 1 & Rejection & 3 years & 2 years & Yes \\
\hline 8 & 66 & Trauma & 2 & Rejection & 34 months & 25 months & No \\
\hline 9 & 57 & Pseudophakic CO & 3 & Rejection & 2 years & 2 years $^{c}$ & No \\
\hline 10 & 73 & Pseudophakic CO & 1 & Rejection & 4 years & 25 months & No \\
\hline 11 & 43 & Stevens-Johnson syndrome & 3 & Rejection & 3 months & 6 weeks & Yes \\
\hline 12 & 44 & CHED & 3 & Rejection & 31 years & $\sim 20$ years & No \\
\hline 13 & 22 & Keratoconus & 2 & Rejection & 12 months & 2 months & No \\
\hline 14 & 69 & Pseudophakic CO & 2 & Rejection & 7 weeks & 4 weeks & Yes \\
\hline 15 & 53 & Buphthalmos & 1 & Rejection & 4 years & 2 years & No \\
\hline 16 & 64 & IK & 3 & Rejection & 23 years & 16 years & No \\
\hline 17 & 19 & Keratoconus & 1 & Rejection & 5 months & 4 months & Yes \\
\hline 18 & 33 & Fuchs' endothelial disease & 1 & Astigmatism & 27 months & - & No \\
\hline 19 & 70 & Fuchs' endothelial disease & 1 & $\begin{array}{l}\text { Recurrent } \\
\text { endothelial disease }\end{array}$ & 6 years & - & No \\
\hline
\end{tabular}

$\mathrm{CO}$, corneal oedema; CHED, congenital hereditary endothelial dystrophy; IK, interstitial keratitis.

${ }^{a}$ Number of previous penetrating transplants in the ipsilateral eye prior to the surgical procedure in which the specimen examined was removed.

${ }^{b}$ Whether or not topical corticosteroid was being administered regularly to the graft immediately prior to graft replacement.

'Irreversible rejection episode 5 weeks following transplantation.

was replaced due to unmanageable astigmatism, and 1 replaced due to development of Fuchs' endothelial dystrophy in the donor cornea. Patient details, including primary corneal diagnosis, interval posttransplant and post-rejection, are shown in Table I. Of the grafts which failed due to rejection, 9 were first, 4 were second and 4 were third grafts in the involved eye.

Regional loss of keratocytes was noted in all the rejected grafts examined (Fig. 1). While keratocyte loss occurs in conditions other than graft rejection (such as de-epithelialisation), the pattern observed in these specimens is consistent with an allogeneic response. Direct apposition of mononuclear cells to keratocyte nuclei was seen in the stroma of all 17 rejected corneas, most commonly adjacent to regions of the stroma in which keratocyte nuclei were absent. Occasional apoptotic cells were identified in these areas in 5 of 12 of the rejected corneas on morphological characteristics (Fig. 2), and in 4 of 12 by ISTR (Fig. 3). The 5 other rejection specimens were excluded from this analysis on account of polymorphonuclear leucocyte infiltration - these were each removed at intervals from 4 to 6 weeks following rejection onset. Neither leucocytekeratocyte apposition nor keratocyte apoptosis was observed in the non-rejected corneal specimens. Moreover, we have not seen these features in specimens of non-allogeneic corneal inflammation or in donor corneas following storage for transplantation.

Immunohistochemical staining with antibody to leucocyte common antigen indicated a chronic stromal inflammatory infiltrate in 15 of 17 of the rejected transplants (Fig. 4) and the T cell lineage was confirmed by the anti-CD3 antibody in each case. Proportions of graft-infiltrating cells which expressed CD68 and $\alpha$-1-antichymotrypsin markers corresponded in all cases except one, suggesting that antibodies to these determinants identified macrophages. Only 4 rejection specimens stained with the natural killer cell anti-CD57 antibody. In these specimens, $5 \%$ or less of the graft-infiltrating cells stained, but each was removed within 4 months of rejection, indicating a possible role of natural killer cells in early acute allograft rejection. HLA-DR antibody staining was found in the stroma in 15 of 17 of the rejected grafts, but not in the 2 control specimens. There was no clear correlation apparent between HLA-DR expression and that of any other antigen. B cells, as identified by anti-CD20 staining, were not observed in any specimen. No inflammatory cells were found in the stroma of the 2 non-rejected control graft specimens. An appropriate staining pattern of positive control tonsil sections was verified in respect of each antibody.

The endothelial monolayer was attenuated in 10 rejection specimens and completely absent in 7. Histopathological findings are summarised in Table II. While the number of specimens in this series is too small to allow multivariate analysis, those specimens with neutrophil infiltrates were all removed within 6 weeks of rejection onset and those with the largest mononuclear cell infiltrate were removed within 4 months. There was no obvious correlation between interval after transplantation, 


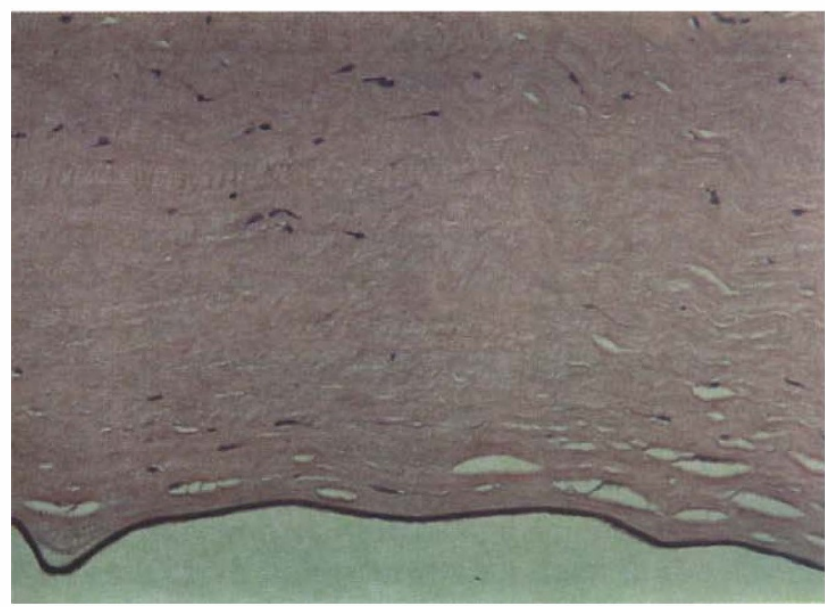

Fig. 1. Keratocyte loss is seen in this region of graft stroma. $(H \& E$, original magnification $\times 200$.)

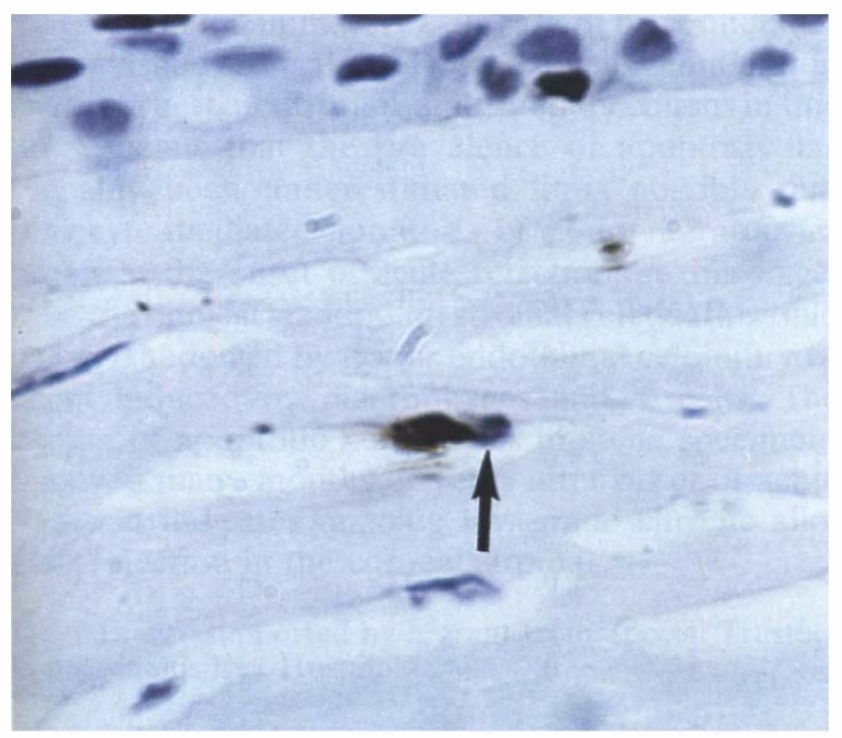

Fig. 3. Keratocyte apoptosis (brown) stained by in situ $3^{\prime}$ tailing reaction. A mononuclear cell (arrow) is situated adjacent to this keratocyte. (Haematoxylin counterstain, original magnification $\times 1000$.)

age, primary corneal diagnosis, number of previous grafts or topical steroid dose prior to graft replacement.

\section{DISCUSSION}

In this series of patients with diverse corneal disease prior to transplantation, grafts with the largest inflammatory cell infiltrate were those removed at the shortest interval following rejection. In view of the shorter reported graft survival in recipient beds with high numbers of antigen presenting cells, ${ }^{31}$ this study suggests that the longest possible delay before graft replacement following rejection would be most beneficial to survival of the subsequent graft. Graftinfiltrating cells were predominantly $\mathrm{T}$ lymphocytes and macrophages. A small number of natural killer

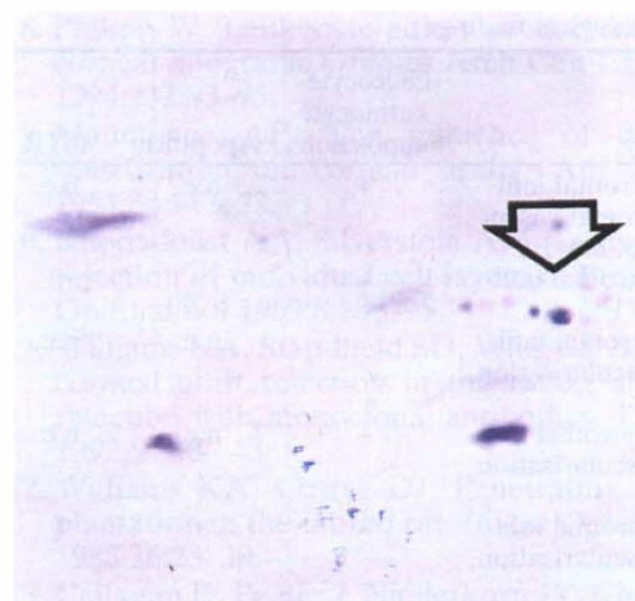

Fig. 2. Apoptosis (arrow) in the corneal stroma in a graft with few infiltrating cells. Although these were infrequently observed, the process of apoptosis lasts only a few hours and even a few observed apoptoses may represent a significant rate of cell loss. (H\&E, original magnification $\times 1000$.)

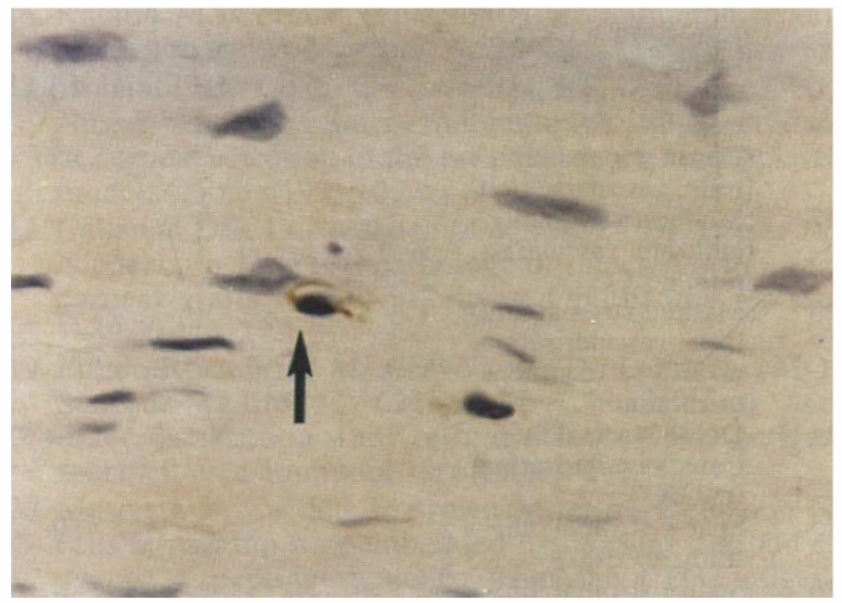

Fig. 4. Mononuclear cells staining with antibody to leucocyte common antigen within graft stroma. Note the apposition of one mononuclear cell to a keratocyte (arrow). (Haematoxylin counterstain, original magnification $\times 1000$.)

cells was found in those grafts removed earliest following rejection - a finding not reported previously and suggesting possible involvement of this cell type in acute rejection at an earlier phase than it was possible for us to study. B cells were not a component of the infiltrate in any specimen. While the applicable range of monoclonal antibodies to inflammatory cell surface determinants is more restricted for formalin-fixed than frozen specimens, superior preservation of morphological features is obtained. In one previous corneal immunohistochemistry study, the endothelial layer of the cornea was absent in $84 \%$ of frozen specimens. ${ }^{32}$ Thus in this study, good morphological preservation allowed more detailed observation of cell interactions in rejected cornea. 
Table II. Pathological findings

\begin{tabular}{|c|c|c|c|c|c|c|c|c|c|c|}
\hline $\begin{array}{l}\text { Patient } \\
\text { no. }\end{array}$ & Histology & $\begin{array}{l}\text { Leucocyte- } \\
\text { keratocyte } \\
\text { apposition }\end{array}$ & Apoptosis & ISTR & $\begin{array}{c}\text { MNC } \\
(\mathrm{CD} 45) \\
(\% \mathrm{GIC})\end{array}$ & $\begin{array}{c}\text { T cells } \\
(\% \text { MNC) }\end{array}$ & $\begin{array}{l}\text { B cells } \\
(\% \text { MNC) }\end{array}$ & $\begin{array}{l}\text { NK cells } \\
(\% \text { GIC })\end{array}$ & $\begin{array}{l}\text { Macrophages } \\
(\% \text { MNC) }\end{array}$ & $\begin{array}{l}\text { HLA-DR } \\
(\% \text { GIC })\end{array}$ \\
\hline 1 & $\begin{array}{l}\text { Dense stromal infil- } \\
\text { trate, stromal vascu- } \\
\text { larisation, few EC }\end{array}$ & + & n.e. & n.e. & ++ & +++ & 0 & 0 & ++ & + \\
\hline 2 & $\begin{array}{l}\text { Sparse stromal infil- } \\
\text { trate, no EC }\end{array}$ & + & - & 0 & +++ & ++ & 0 & 0 & ++ & + \\
\hline 3 & $\begin{array}{l}\text { Dense stromal infil- } \\
\text { trate, vascularisation, } \\
\text { few EC }\end{array}$ & + & n.e. & n.e. & +++ & ++ & 0 & \pm & +++ & + \\
\hline 4 & $\begin{array}{l}\text { Marked stromal infil- } \\
\text { trate, vascularisation, } \\
\text { no EC }\end{array}$ & + & n.e. & n.e. & ++ & ++ & 0 & 0 & ++ & + \\
\hline 5 & $\begin{array}{l}\text { Sparse stromal infil- } \\
\text { trate, vascularisation, } \\
\text { few EC }\end{array}$ & + & + & 0 & ++ & ++ & 0 & 0 & ++ & ++ \\
\hline 6 & $\begin{array}{l}\text { Sparse stromal infil- } \\
\text { trate, few EC }\end{array}$ & + & - & 0 & ++ & ++ & 0 & 0 & +++ & + \\
\hline 7 & $\begin{array}{l}\text { Sparse stromal infil- } \\
\text { trate, vascularisation, } \\
\text { no EC }\end{array}$ & + & - & 0 & ++ & ++ & 0 & 0 & ++ & 0 \\
\hline 8 & $\begin{array}{l}\text { Moderate stromal } \\
\text { infiltrate, retrocorneal } \\
\text { membrane }\end{array}$ & + & - & 0 & ++ & ++ & 0 & 0 & ++ & ++ \\
\hline 9 & $\begin{array}{l}\text { Marked stromal infil- } \\
\text { trate, vascularisation, } \\
\text { retrocorneal mem- } \\
\text { brane }\end{array}$ & + & + & + & ++ & ++ & 0 & 0 & +++ & +++ \\
\hline 10 & $\begin{array}{l}\text { Sparse stromal infil- } \\
\text { trate, few EC }\end{array}$ & + & - & 0 & + & + & 0 & 0 & + & 0 \\
\hline 11 & $\begin{array}{l}\text { Dense stromal infil- } \\
\text { trate, vascularisation }\end{array}$ & + & n.e. & n.e. & ++ & +++ & 0 & 0 & ++ & \pm \\
\hline 12 & $\begin{array}{l}\text { Moderate stromal } \\
\text { infiltrate, vascularisa- } \\
\text { tion, no EC }\end{array}$ & + & + & + & ++ & ++ & 0 & 0 & ++ & + \\
\hline 13 & $\begin{array}{l}\text { Marked stromal infil- } \\
\text { trate, vascularisation, } \\
\text { no EC, retrocorneal } \\
\text { membrane }\end{array}$ & + & + & + & +++ & ++ & 0 & \pm & ++ & ++ \\
\hline 14 & $\begin{array}{l}\text { Dense stromal infil- } \\
\text { trate, vascularisation, } \\
\text { few EC }\end{array}$ & + & n.e. & n.e. & ++ & ++ & 0 & \pm & +++ & + \\
\hline 15 & $\begin{array}{l}\text { Sparse stromal infil- } \\
\text { trate, no EC }\end{array}$ & + & - & 0 & \pm & \pm & 0 & 0 & +++ & + \\
\hline 16 & $\begin{array}{l}\text { Sparse stromal infil- } \\
\text { trate, vascularisation, } \\
\text { few EC }\end{array}$ & + & - & 0 & ++ & ++ & 0 & 0 & + & ++ \\
\hline 17 & $\begin{array}{l}\text { Marked stromal infil- } \\
\text { trate, few EC }\end{array}$ & + & + & + & +++ & +++ & 0 & + & ++ & + \\
\hline 18 & $\begin{array}{l}\text { No infiltrate, EC } \\
\text { normal }\end{array}$ & - & - & 0 & 0 & \pm & 0 & 0 & \pm & 0 \\
\hline 19 & $\begin{array}{l}\text { No infiltrate, guttata } \\
\text { on Descemet's mem- } \\
\text { brane, few EC }\end{array}$ & - & - & 0 & 0 & 0 & 0 & 0 & 0 & 0 \\
\hline
\end{tabular}

ISTR, in situ 3'-tailing reaction; GIC, graft stroma infiltrating cells; MNC, mononuclear cells; NK, natural killer cells; EC, endothelial cells; n.e., not examined (sections with polymorphonuclear leucocyte infiltration, unsuitable for identification of apoptoses).

Apoptosis - programmed cell death - is characterised by destruction of the structural organisation of the nucleus, resulting in dense masses of chromatin at the periphery of the cell, ${ }^{26}$ and occurs when a cell is signalled to activate an internally encoded suicide programme. ${ }^{33}$ Apoptosis is involved in both physiological cell deletion and pathological states, and cytotoxic $\mathrm{T}$ lymphocytes contain granule proteins that can induce apoptosis in target cells. ${ }^{34}$ Apoptotic cell death has recently been reported as a component of liver allograft rejection, the extent of apoptosis correlating with the classic indicators of graft rejection. ${ }^{35}$ Morphological features and in situ end-labelling of double-strand DNA breaks can be used to distinguish the two generally recognised distinct mechanisms of cell death: apoptosis and necrosis. The end-labelling method used in this study uses TdT to add biotin-labelled dATP to the 3'hydroxyl termini of broken DNA fragments. This and similar labelling techniques are not specific for apoptosis and must be correlated with morphological criteria of apoptosis, ${ }^{28}$ as in this study. 
We found regional keratocyte loss in the stroma of rejected transplants. Absence of keratocytes following rejection has been reported by other investigators in human ${ }^{6}$ and rabbit ${ }^{10}$ corneas. We consider that the additional phenomena which we observed of mononuclear cell-keratocyte apposition and keratocyte apoptosis may be causally related. These observations are consistent with a model whereby apoptotic cell death is mediated by alloantigen-specific infiltrating $\mathrm{T}$ lymphocytes through the production of cytokines or by cytotoxic $\mathrm{T}$ lymphocyte-induced target cell death. As the shortest interval following onset of rejection at which a specimen was available was 4 weeks, these features were seen in the stroma late in the rejection episode and in many specimens in the absence of any signs of epithelial or endothelial inflammation. It is a limitation of the methods available for detection of apoptosis that apoptosis in inflammatory cells cannot be confidently distinguished from that in corneal cells: elimination of the earliest, neutrophil-infiltrated specimens in this study means that the prevalence of apoptosis has probably been underestimated. It is possible that leucocyte-mediated apoptosis of donor keratocytes begins at the onset of acute rejection: at this stage, from the clinical standpoint, stromal cell death would be overshadowed by donor endothelial cell injury or death induced by macrophages and $T$ cells. The finding of apoptotic keratocytes in some specimens removed many months or years after onset of acute rejection indicates ongoing low-grade chronic allograft rejection in the corneal stroma.

D.F.P.L. was supported by a grant from Special Trustees of Moorfields Eye Hospital.

Key words: Corneal transplantation, Allograft, Rejection, Apoptosis, Immunohistochemistry.

\section{REFERENCES}

1. Williams KA, Roder D, Esterman A, Muehlberg SM, Coster DJ. Factors predictive of corneal graft survival: report from the Australian Corneal Graft Registry. Ophthalmology 1992;99:403-14.

2. Vail A, Gore SM, Bradley BA, Easty DL, Rogers CA. Corneal graft survival and visual outcome. Ophthalmology 1994;101:120-7.

3. Price FW, Whitson WE, Collins KS, Marks RG. Fiveyear corneal graft survival. A large single-center patient cohort. Arch Ophthalmol 1993;111:799-805.

4. Levenson JE, Brightbill FS. Endothelial rejection in human transplants. Arch Ophthalmol 1973;89:489-92.

5. Pepose JS, Nestor MS, Gardner KM, Foos RY, Pettit $\mathrm{TH}$. Composition of cellular infiltrates in rejected human corneal allografts. Graefes Arch Clin Exp Ophthalmol 1985;222:128-33.

6. Pepose JS, Gardner KM, Nestor MS, Foos RY, Pettit TH. Detection of HLA class I and II antigens in rejected human corneal allografts. Ophthalmology 1985;92:1480-4.

7. Whitcup SM, Nussenblatt RB, Price FW, Chan C-C. Expression of cell adhesion molecules in corneal graft failure. Cornea 1993;12:475-80.
8. Philipp W. Leukocyte adhesion molecules in rejected corneal allografts. Graefes Arch Clin Exp Ophthalmol 1994;232:87-95.

9. Maumenee AE. The influence of donor-recipient sensitization on corneal grafts. Am J Ophthalmol 1951;34:142-52.

10. Khodadoust AA, Silverstein AM. Transplantation and rejection of individual cell layers of the cornea. Invest Ophthalmol 1969;8:180-95.

11. Williams KA, Standfield SD, Wing SJ, et al. Patterns of corneal graft rejection in the rabbit and reversal of rejection with monoclonal antibodies. Transplantation 1992;54:38--43.

12. Williams KA, Coster DJ. Penetrating corneal transplantation in the inbred rat. Invest Ophthalmol Vis Sci 1985;26:23-30.

13. Callanan D, Peeler J, Niederkorn JY. Characteristics of rejection of orthotopic corneal allografts in the rat. Transplantation 1988;45:437-43.

14. Kanai A, Polack FM. Ultramicroscopic changes in the corneal graft stroma during early rejection. Invest Ophthalmol 1971;10:415-23.

15. Treseler PA, Sanfilippo F. The expression of major histocompatibility complex and leucocyte antigens by cells in the rat cornea. Transplantation 1986;41:248-52.

16. Katami M. Corneal transplantation: immunologically privileged status. Eye 1991;5:528-48.

17. Holland EJ, Chan C-C, Wetzig RP, Palestine AG, Nussenblatt RB. Clinical and immunohistologic studies of corneal rejection in the rat penetrating keratoplasty model. Cornea 1991;10:374-80.

18. Callanan DG, Luckenbach MW, Fischer BJ, Peeler JS, Niederkorn JY. Histopathology of rejected orthotopic corneal grafts in the rat. Invest Ophthalmol Vis Sci 1989;30:413-24.

19. Pulido R, Cebrian M, Acevedo A, De Landazuri MO, Sanchez-Madrid F. Comparative biochemical and tissue distribution study of four distinct CD45 antigen specificities. J Immunol 1988;140:3851-7.

20. Mason DY, Cordell J, Brown M, et al. Detection of cells in paraffin wax embedded tissue using antibodies against a peptide sequence from the CD3 antigen. J Clin Pathol 1989;42:1194-200.

21. Cartun RW, Coles FB, Pastuszak WT. Utilization of monoclonal antibody L26 in the identification and confirmation of B-cell lymphomas. A sensitive and specific marker applicable to formalin- and B5-fixed, paraffin-embedded tissues. Am J Pathol 1987;129: 415-21.

22. Lanier LL, Le AM, Phillips JH, et al. Subpopulations of natural killer cells defined by expression of the Leu-7 (HNK-1) and Leu-11 (NK-15) antigens. J Immunol 1983;131:1789-96.

23. Pulford KAF, Rigney EM, Micklem KJ, et al. KP1: a new monoclonal antibody that detects a monocyte/ macrophage associated antigen in routinely processed tissue sections. J Clin Pathol 1989;42:414-21.

24. Meis JM, Osborne BM, Butler JJ. A comparative marker study of large cell lymphoma, Hodgkin's disease, and true histiocytic lymphoma in paraffinembedded tissue. Am J Clin Pathol 1986;86:591-9.

25. Marder RJ, Variakojis D, Silver J, et al. Immunohistochemical analysis of human lymphomas with monoclonal antibodies to $\mathrm{B}$ cell and Ia antigens reactive in paraffin sections. Lab Invest 1985;52:497-504.

26. Wyllie AH, Kerr JFR, Currie AR. Cell death: the significance of apoptosis. Int Rev Cytol 1980;68: 251-306. 
27. Cree IA, Nurbhai S, Milne G, Beck JS. Cell death in granulomata: the role of apoptosis. J Clin Pathol 1987:40:1314-9.

28. Ansari B, Coates PJ, Greenstein BD, Hall PA. In situ end-labelling detects DNA strand breaks in apoptosis and other physiological and pathological states. J Pathol 1993;170:1-8.

29. Savill JS, Wyllie AH, Henson JE, Walport MJ, Henson PM, Haslett C. Macrophage phagocytosis of aging neutrophils in inflammation. Programmed cell death in the neutrophil leads to its recognition by macrophages. J Clin Invest 1989;83:865-75.

30. Nakamura T, Sakai T, Hotchi M. Histochemical demonstration of DNA double strand breaks by in situ 3 '-tailing reaction in apoptotic endometrium. Biotech Histochem 1995;70:33-9.

31. Williams KA, White MA, Ash JK, Coster DJ. Leucocytes in the graft bed are associated with corneal graft failure: analysis by immunohistology and actuarial graft survival. Ophthalmology 1989;96:38-44.

32. Goldberg MF, Ferguson TA, Pepose JS. Detection of cellular adhesion molecules in inflamed human corneas. Ophthalmology 1994;101:161-8.

33. Boise LH, Gonzalez-Garcia M, Postema CE. bcl-x, a bcl-2-related gene that functions as a dominant regulator of apoptotic cell death. Cell 1993;74:597-608.

34. Tien Q, Streuli M, Saito H, Schlossman SF, Anderson P. A polyadenylate binding protein localised to the granules of cytolytic lymphocytes induces DNA fragmentation in target cells. Cell 1991;67:629-39.

35. Krams SM, Egawa H, Quinn MB, Villanueva JC, Garcia-Kennedy R, Martinez OM. Apoptosis is a mechanism of cell death in liver allograft rejection. Transplantation 1995;59:621-5. 